\title{
History of the Egyptian Post Authority in Modern Egypt 1805-1952
}

\author{
Mariam Magdy Boshra \\ Tourist Guidance Department, Minia University \\ Enas Fares Yehia \\ Tourist Guidance department, Minia University \\ Princess Nourah Bint Abdulrahman University \\ Doaa Abdel-Motaal Ahmed \\ Tourist Guidance Department, Minia University \\ Mohamed Atef Abdel-maksood \\ History Department- Minia University
}

\begin{abstract}
Egypt was one of the first Arab countries to issue post stamps in 1866. It is also one of the first countries in the Middle East to establish a post museum in 1934 that includes a large set of rare collections of Egyptian post history; the most prominent of which is a hand-drawn plate of post stamps that embody the view of the pyramids and Sphinx for which the artist used 15 thousand stamps. Therefore, postal services have become the features of the era in which we live, and the more this service advances, the more the society as a whole develops, as the post is the focus of communications and meetings among all countries of the world. This would be achieved through the postal services provided by governments, which include letters, express mail, publications, samples and parcels. This is in addition to postal transfers to government departments and individuals; this article discusses a long history of postal services with its features along modern Egyptian history, the most important point that Egypt possesses a postal museum in Cairo regarded as a witness for this long history.
\end{abstract}

Keywords: Postal Services, Post Museum, post Authority, stamps.

\section{Introduction}

The Egyptian history confirms that the ancient Egyptians were the first to use post in the ancient world around 2000 BC. Followed by the Ruling Family in China about 1000 years BC, Which the first country to establish a postal system with stations to receive post in different regions of the empire. It also had the largest postal communications network, and the center of the network was in the city of "Beijing", which had branches that reached 25,000 stations 
spread throughout the empire. Some historians have also emphasized that the Greek and Roman invaders had transmitted the postal system from Egypt to their countries ${ }^{1}$.

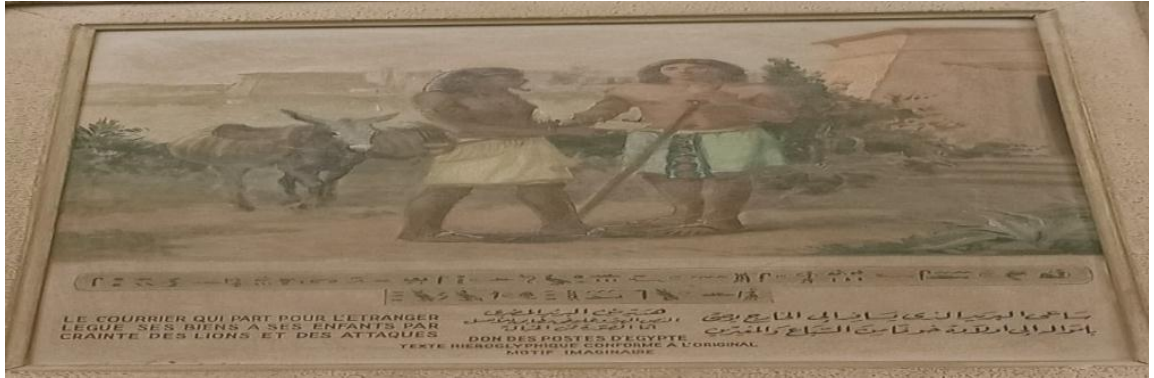

Fig. (1) Showing the postman leaving a will for his children.

Source: Post Museum at Al-Attaba "Photographed by the researcher"

After that the Ptolemies established a postal system that was accurate and fast in transporting official messages to countries. Therefore, they set up post stations between the capital and cities and established post offices that included a large number of postmen who transported messages and postal parcels at the time of their arrival. In addition, each office had a staff member who recorded the messages when they were sent or received, and recorded the names of the postmen responsible for them. Moreover, in that period a letter was sent from Fayoum to Alexandria in only four days ${ }^{2}$.

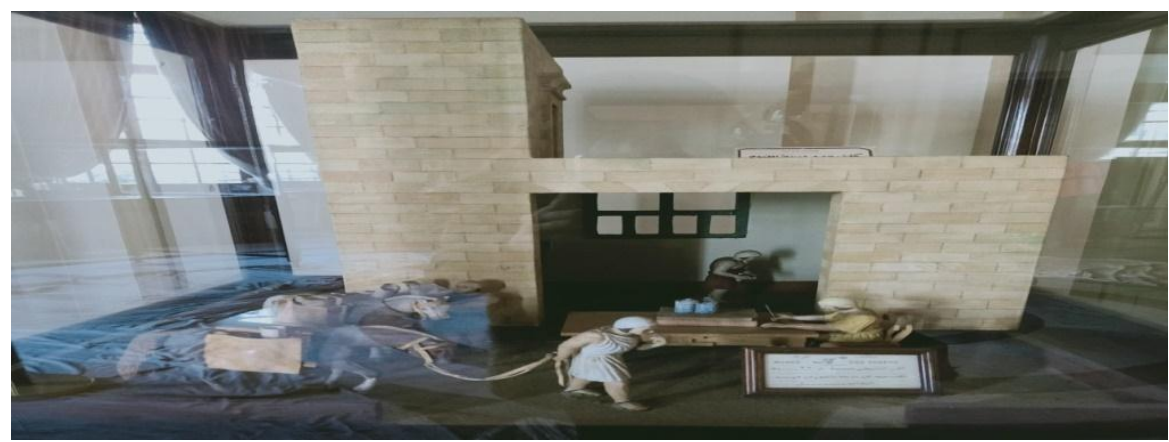

Fig. (2) of a post office in El Fayoum during the Ptolemaic era.

Source : Post Museum at Al-Attaba "Photographed by the researcher"

The Romans did not change much in the internal administration of Egypt. However, they knew the importance of the political, military and administrative life of the country through the postal services. Thus, they used the vehicles by horse-drawn carriages to transport the mail and prepared stations for resting between the roads. In addition, there were orders for the

$$
\begin{aligned}
& \text { ـ ـ إبر اهيم مرزوق ، " تاريخ طو ابع البريد : البداية والهواية"، (الطبعة الاولي ، الدار الثقافية للنشر، القاهرة ، ـ . ب)، }
\end{aligned}
$$

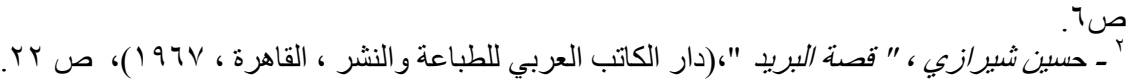


guards to protect the postmen ${ }^{3}$ until the postal system gradually began to degenerate, under the rule of Emperor Justinian who replaced horses with donkeys ${ }^{4}$.

After the Arabs entered Egypt, The postal system in that period became one of the important jobs that the state relied on to send its correspondence in order to link the Caliphate with each other. Therefore, the Arabs took an interest in the post system, like the country of the Persians when they expanded to know about the conditions of the Islamic countries ${ }^{5}$ by conveying instructions from governors to the caliphate. The Arabs also used horses to transport the post, and there were rest houses for the postman and the animals to reach the next point ${ }^{6}$. In addition, the princes cared about the postal system during the reign of the Umayyad dynasty. And the Abbasids followed them when they came to rule by taking great interest in the post by establishing six major roads to establish a post system in their country. In addition, the first to establish a "the post of postmen" is "Al Mu'ezz". Whom they used to walk tens of miles a day?

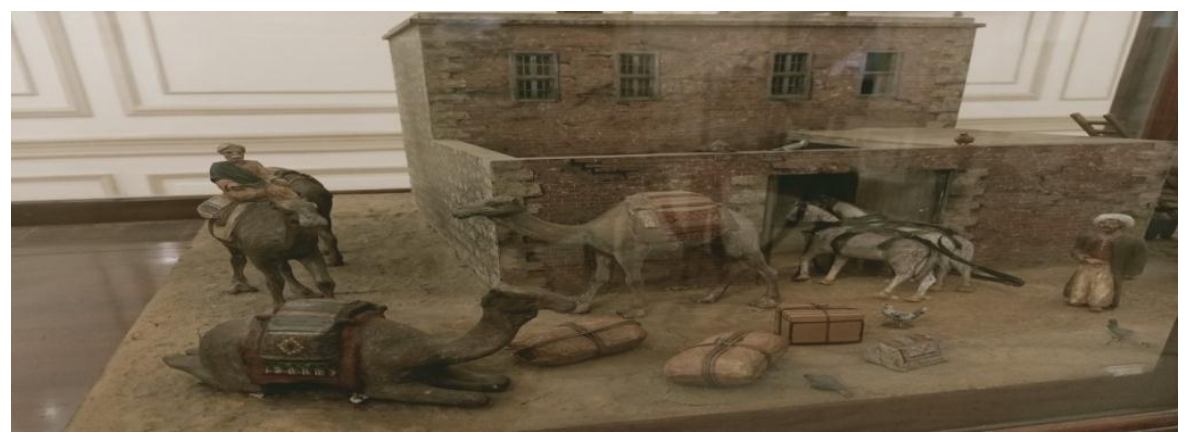

Fig. (3) of a postman and animals' rest place in the Islamic era.

Source : Post Museum at Al-Attaba "Photographed by the researcher"

Mail also flourished in the Mamluk era, postmen wore a badge of their own to distinguish them from others. In addition, they continued to use camels and homing pigeons to send their messages, until the post was organized in the

$$
\begin{aligned}
& \text { " ـ عبد الحليم أبو صير ، اسماعيل عبد الفتاح ، " جوله داخل متحف البريد"، (الهيئة العامة للاستعلامات ، القاهرة ، } \\
& \text {.1. صل (1999 }
\end{aligned}
$$

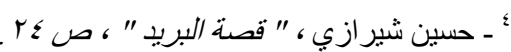

5 - In the Islamic era, there were what so-called post agencies. And the Passengers traveling to send messages used to stay there to rest along with their animals. These agencies were characterized by simplicity in construction. And, the total number of post agencies reached 200 agencies; For more see: Ibrahim Marzouk, "The History of Post Stamps: The Beginning and the Hobby," p. 22.

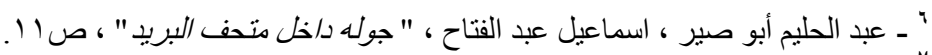

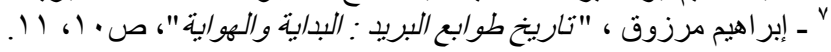


nineteenth century to transport messages from the capital to all cities ${ }^{8}$. Moreover, during the reign of Sultan Al-Zahir Baybars, the postal system developed remarkably in a way that helped to face the Tatar and Mongol raids in the due time. It also helped him to inspect the state administrations and get acquainted with all the small and great things about the Walis and rulers 9

Messages continued to be sent by postmen. And the Post offices at that period was received the fees of clearance from the owners of messages in advance and others accepted the postponement of payment provided that they know the name of the postman and guarantee him. In addition, a stamp bearing the letters "PD" was placed on the letter indicating the necessity of collecting the fees from the receiver ${ }^{10}$. Moreover, the number of post boxes reached 541 boxes in 1780 .

\section{Diversity of the post means of transport:}

There was diversity of post means through Egyptian history, which evolved over the years.

First; Homing pigeons: the first carrier of messages known to mankind.

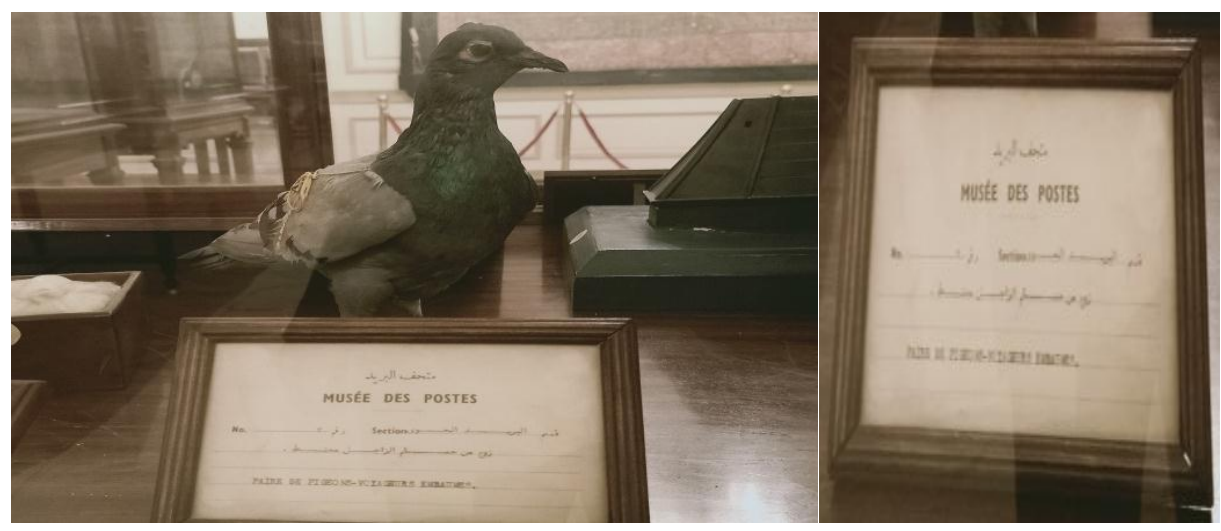

Fig. (4) of a model of embalmed homers.

Source : Post Museum at Al-Attaba "Photographed by the researcher"

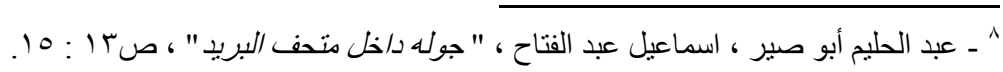

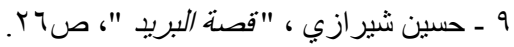

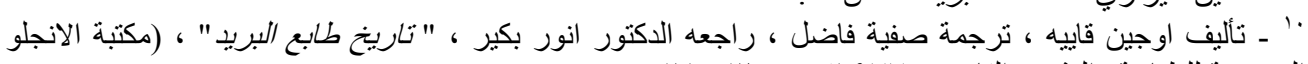

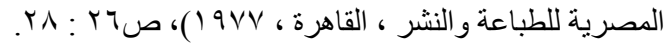


In the early twelfth century, Egypt enjoyed the precise and speedy post system, known as the "Pigeon Post". It was first organized by Sultan Nur adDin $^{11}$ to convey government messages. Therefore, he established stations for that system on the most important roads of the Sultanate. The Arabs also took care of the homing pigeons to be used to convey messages at times of war in order to keep contact among a number of major cities in the Islamic state. The Arabs used this airmail in their wars, the number of pigeons during that period at one thousand nine hundred pigeons, in addition to describing it as the faithful Messenger ${ }^{12}$.

\section{Second: Tattoo Post ${ }^{13}$}

It was one of the most dangerous types of post that was used in wartime and was one of the most important means of transporting military post. The carrier of this type of post was chosen after he proved his worth in horse riding, his prowess in running, fleeing from enemies, his knowledge of methods and his ability to hide messages. He was greatly appreciated by the Roman emperors; the postman was called at that time the "guerrilla postman" as they used to cut their hair and write the message on the skin in tattoos to be sent to the commanders. Then the carrier set to send the message with his head covered with a wig until he delivered the message to its owners. If the addressee could not read the message in case his hair appeared, the commander would order his hair to be cut as the courier used to travel long distances for several weeks. The seriousness of this type begins after the message is delivered, where the commander orders the beheading of this courier, and then he burns it himself so that the message does not fall into the hands of the enemies ${ }^{14}$.

\section{Third: Water Post:}

This type is an old means of post transport that was used during wars but in a limited way in case it was impossible to communicate in any other way. This was due to its slowness and its inability to exchange messages between the two parties according to the direction of the current. Sea post was used for the first time between Britain and France in 1633. The messages were

${ }^{1-}$ Sultan Nur ad-Din : interested in this airmail and built special towers for that purpose on which guards were appointed to monitor the arrival of pigeons day and night. The distance between each tower and the other was twelve miles. Also, he engraved his name on the beak of each pigeon, and he allocated an individual number to each pigeon to go and an even number for those which go back home.

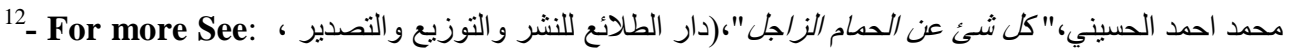

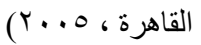

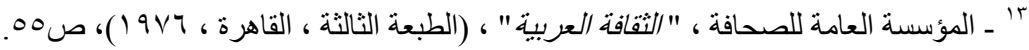

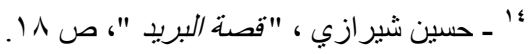


transported by ship, which took long hours (about 100 hours). After the use of new ships, the duration was reduced to 64 hours, and this type was called "express post ships". However, this service ceased to function in January 1931 after crossing the first French aircraft in the Atlantic Ocean that transported post from France to South America on May 12, 1930. This type continues until today to transport parcels and large goods between countries.

The fees of sea post varied from one country to another according to time and distance. This is evident in the transportation of consignments from the Khedive Post Ship Company in Alexandria to transfer some foreign post authorities during the period from June 19, 1935: July 31, 1937 through the two ships (Ismail, Muhammad Ali), (1779 pounds and $974 \mathrm{~mm})^{15}$ according to the memorandum submitted by the financial agent to the transportation agent on the supply of the Khedive Post Company on November 28, $1938^{16}$.

As for the fees for transporting consignments from the Khedive Post Shipping Company for Sudan Post between 30 July: 3 August 1943, it was 158 pounds and $648 \mathrm{~mm}$. According to the memorandum submitted by the Director of the Post Authority to the Undersecretary of the Ministry of transportations on April 3, 1944 ${ }^{17}$. During that period, about 1276 post messages were transported from Suez to Sudan by ship (Taloudi) on July 31, 1943. About 600 post messages were transported from Suez to Sudan by ship (Taef) on August 3, 1943 based on the memorandum issued by the president of the Khedive Post Shipping Company to the Director General of the Post Department ${ }^{18}$.

From this, we conclude that the Khedive Post Shipping Company owned a large number of ships according to the names we received through the documents. These companies were not dealt with either in the case of receipt or delivery except with the original bill of lading to finish the customs duties. This is according to what was stated in the letter issued by the manager of the

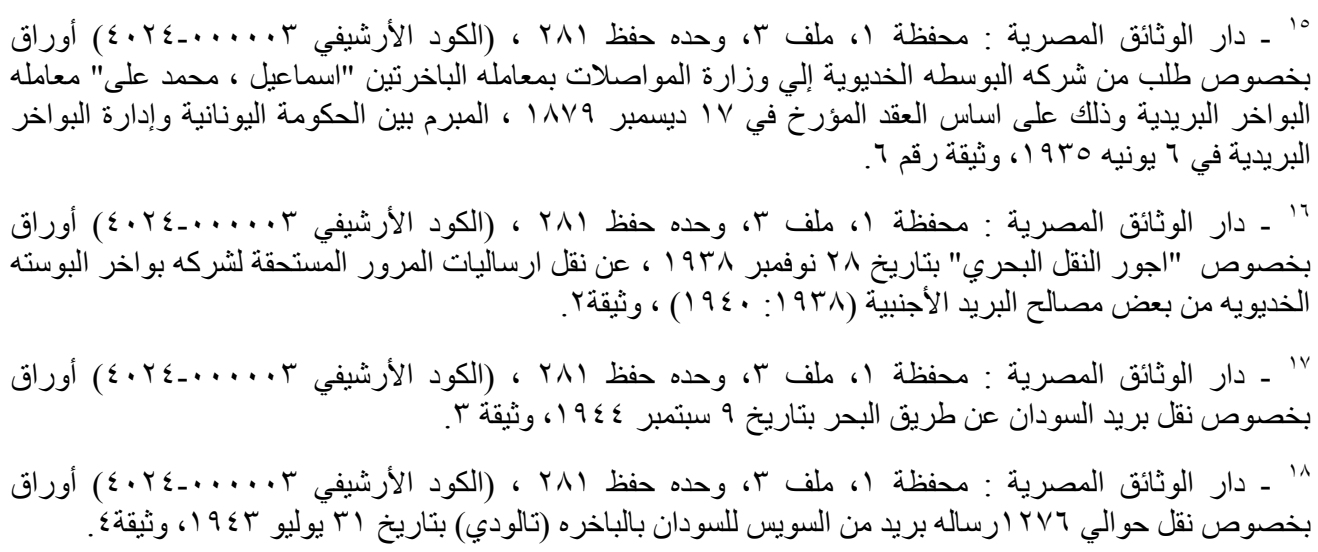


Alexandria Postal District warehouses for ships on March 29, 1967 to the Director of Financial Affairs at the Cairo Post Authority ${ }^{19}$.

\section{Fourth: Land Post:}

Means of transport varied in Egypt, and a number of stamps appeared bearing pictures of the postman riding a bicycle to deliver the messages. It was known as express mail in $1926^{20}$. Then the authority developed its means of transport by using the most modern means of transport to move from one place to another as soon as possible ${ }^{21}$. Moreover, the international post authorities paid attention to putting pictures of many cars bearing thousands of different brands, especially old cars, on their stamps ${ }^{22}$. This is in addition to the Post Museum that contains large numbers of forms of land post transport such as motorcycles, bicycles, cars and trains.

\section{Fifth: Airmail:}

Egypt received the first International Aviation Festival in the airport yard in Heliopolis in February 1910. For this occasion, the Post Authority issued a postcard with a stamp bearing the image of a plane taken from the airport post office. A year after this festival, airmail began on the first flight between some British cities in 1911. It was followed by the first flight to transport a group of post bags between Egypt and Khartoum on January 4, 1914, led by a pilot in the French army called "Mark Pop" who came to Egypt to participate in a festival Aviation established by the government in Heliopolis. In 1919, the first airmail between foreign countries was transferred from London to Paris, and the service expanded to include the post line between London and India in 1929. As for the first trip belonging to the Egyptian Post Authority, it was in August 1921, between Cairo and Baghdad. In addition, the first airline for transporting post between Egypt and England began on April 19, 1929, and for this occasion, the Post Authority issued a 27-mm airmail stamp ${ }^{23}$.

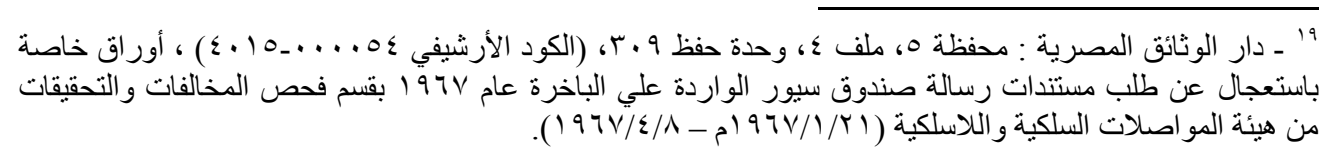

20 - Zeitouna, "150 years of Egyptian Postage 1866-2016" (first edition, Dar El Kutub, Cairo, 2015).

21 - Robert B. partridge، "transport in ancient Egypt in: A companion to ancient Egypt"، Alan B. Lloyd (ed.)( Vol. I، London، 2010،) p 370: 389.

$$
\text { r' - إبر اهيم مرزوق، "تاريخ طوابع البريب : البد/ية والهو/ية"، ص. V. }
$$

23 - Zeitouna, "150 years of Egyptian Postage 1866-2016". 


\section{The Foundation of Egyptian Post Authority:}

It is noticeable in the era of Muhammad $\mathrm{Ali}^{24}$ Pasha that the state was interested in organizing post stations between the capital and its most important centers for sending government correspondence. So, his rule began with an administrative reform among which was the postal service. He established the message transport service by the postman between Cairo and the main cities for communication between the ruler in the citadel and all parts in Upper and Lower Egypt. At that time, the distance from Cairo to Alexandria was 24 hours, while the trips were undertaken weekly to the Middle Egypt (Cairo-Assiut), and monthly to Upper Egypt. With the conquests of Sudan in 1821, the government mail extended to the south for long distances that reached Khartoum during 50 days $^{25}$.

As for the messages of the public during that period, they were not sent through this post, but were sent through Sheikh "Hassan Al-Badihi", in exchange for a sum of money that varied from one to another according to the distance. This was the first post system that served the individuals until $1843^{\mathbf{2 6}}$. The cost ranged between 10 and 30 bars in Middle Egypt, and from one to three piasters for Upper Egypt, and from 3 to 6 piasters for Sudan. And these prices were very high during that period. Therefore, it didn't last long because the government took it upon themselves to send public messages. ${ }^{27}$

Initially the messages were sealed with red wax and a special post stamp. With the development, it was sufficient to use the distinctive seal of the authority with no need to wax. But the wax continued for the recommended and secret letters. This is in addition to the establishment of several

24 - Muhammad Ali: was born on March 4, 1769 in one of the ports of Macedonia in Greece. He practiced trade until he joined the Ottoman army and showed his competence in fighting the French and became the leader of the Albanian soldiers in Egypt. He enjoyed a good relationship with egyptian people. Thus, he was chosen from among the leaders of the people to be their ruler on May 17, 1805 to March 2, 1848. After assuming power, the Ottoman Sultan issued a decree on July 9, 1805, approving the mandate of Muhammad Ali for Egypt; For more see:

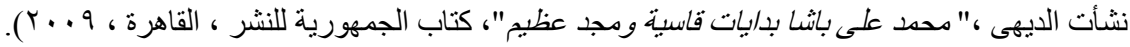

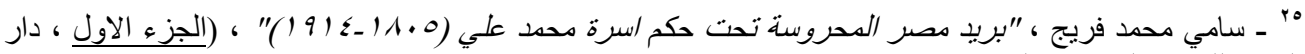

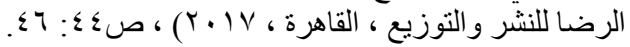

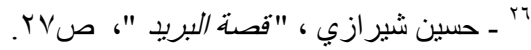

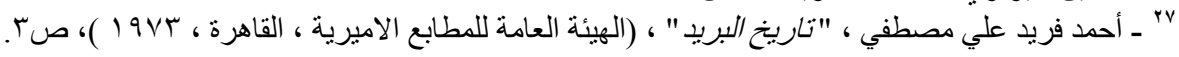


companies and post offices for the purpose of delivering post letters through agents and delegates ${ }^{28}$.

European offices from Austria, Greece, Italy and Russia that were established in Alexandria and Suez from 1831 to 1866 still compete with the government mail until they were closed from 1875 to 1889 . This is in addition to the agreement of boat and camel owners whose hearts were full of hatred and jealousy against the Egyptian Post Authority with those foreigners in providing aid for them to benefit from them when sending their messages. Therefore, Mr. Kaliar, the second director of the Egyptian Post Authority, worked hard in 1876 to close these offices, following the policy of Senior Minister Motsi, the first director of the post authority to set a policy to be followed by the Egyptian Post Authority later on ${ }^{29}$.

In 1864, Khedive Ismail purchased the European Post Company from Senior Motsi $^{30}$. Then bestowed on senior Motsi the title of Bey and appointed him as the director general of Post in $1865^{31}$. Since then, large plates were put on all post offices on which the word "Posta" was written, besides establishing a general post administration in Alexandria. One year after Motsi took over the administration, the Egyptian Post Authority issued the first Egyptian post stamp in $1866^{32}$. The Authority established 13 post boxes throughout Cairo, including the railway station, Azbakeya, Khan Al-Khalili, Al-Gamalia, Bab al-Shaareya, Khan Abu Takiyeh, Al-Ghuryah, Bab Zuweila, Bab Al Khalk, Bulaq and Old Cairo. The Authority stipulated that the letters be sent to Upper Egypt and abroad only, provided that post stamps be placed on these letters.

${ }^{28}$-The mission of freight agents was mainly to organize and arrange the transportation of goods and correspondence through good knowledge of the freight agent of all routes, whether land or sea, to send messages and return quickly. Examples: Waghorn, Briggs, Samuel Shepherd, founder of the Shepherd Hotel in Cairo who was responsible for following up the messages sent from Cairo to Britain.

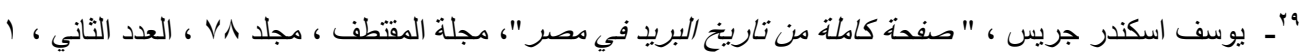

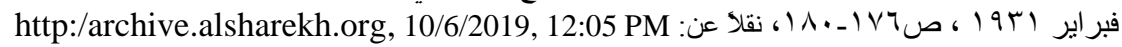

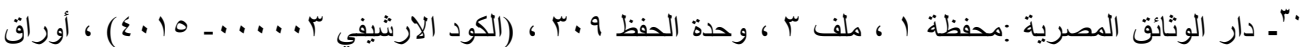

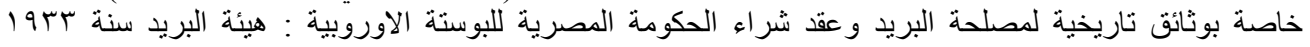
(19Tr/V/10 - (19Tr/Ir/0)

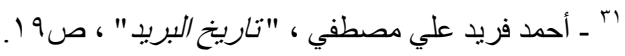
32 - During the era of Khedive Ismail, the first Egyptian post stamp in the Middle East was issued in 1866. This group was printed by the "Bellas Bros" Press in Genoa, Italy. A year later, in 1867, the second Egyptian stamp was issued at the "Abnasunb" printing press in Alexandria. 
Khedive Ismail also appointed one of the post employees in London, Mr. Kaliar, as a head of the Accounts Department of the Government Authority. In 1876, he was appointed as a director of the Postal Service after Motsi's resignation. During the reign of Kaliar Pasha, the fees for ordinary letters were reduced to one piaster instead of one piastre and a half for messages weighing 15 grams. Besides, the forms were printed and the seals were engraved in Arabic and French ${ }^{33}$.

On July 13, 1866, Khedive Ismail ordered some constructions and repairs to the ports of the Egyptian Post ${ }^{34}$ to improve the transportation of consignments. The issued a publication in March 1867 to give clothing to the post employees. In addition, he established a navigational line for the transportation of goods and correspondence in 1873, known as the "Khedive Post Wabours".

Here, we affirm that the purchase of the European Post Company does not negate the existence of an Egyptian post authority that had been transporting public messages since the era of Muhammad Ali called "Traffic Authority" that transport public messages for a fee. This was confirmed after researching and reviewing the files that were kept inside the National Archives, which proved that information ${ }^{35}$.

In addition, the Post Authority continued to establish many post offices, including the establishment of a post office in Minia Governorate on October 23, 1888. After submitting a note from the Post Authority to the Ministry of Public Works and then to the Finance, committee allow the use of 906 pounds to establish a post office in Minia. The committee decided to open a credit in the budget of this ministry for the establishment of the office ${ }^{36}$. Also, the Post Authority sent a note to the Prime Minister on March 26, 1906, requesting that orders be given to the employees when sending their letters to Cairo or Alexandria to mention "the house number, street name, and

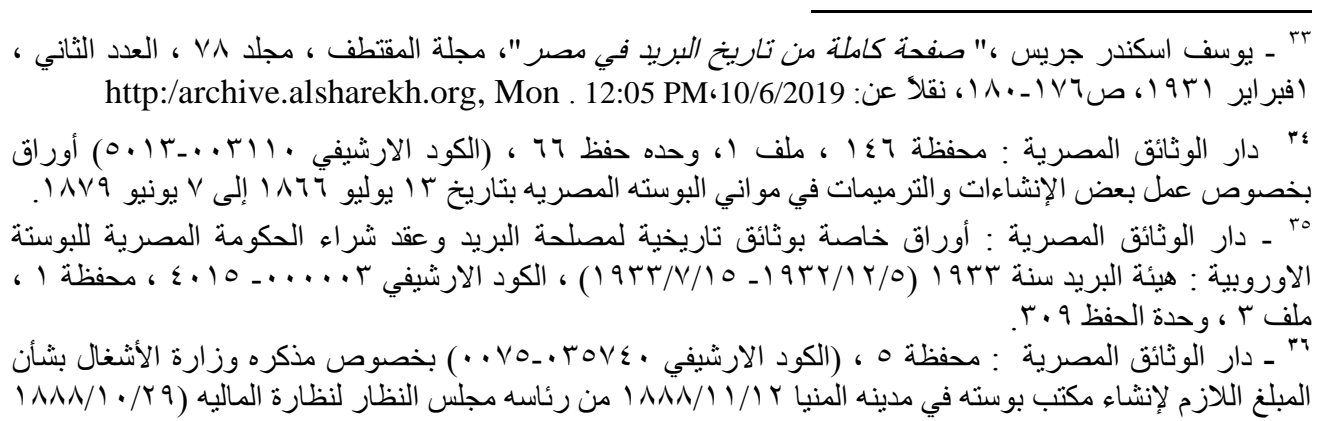


neighborhood" because this helps to speed up the distribution and to comfort the postmen ${ }^{37}$.

On October 16, 1919, a note was submitted to the cabinet from the Minister of Transportation with regard the establishment of a new branch in the Post Authority called "Deposit Account", the project was approved on November $1919^{38}$. In the same year, the Ministry of Transportation suggested, in agreement with the Ministry of Finance, that a slight increase be added to the fees collected by the post administration From April 1920. This after the cabinet decided to grant the employees of the Post Department a permanent bonus of $20 \%$ on the salaries starting from September 15, 1919, this allowance caused a deficit in the budget of the Post Authority. Therefore, the ministry suggested an increase in the fees to cover the deficit of the bonus granted $^{39}$.

In the beginning, the Egyptian Post Authority joined the Ministry of Public Works in 1865. While in 1866, it joined the General Finance Office, then the Ministry of Interior in 1867, in 1875, the Ministry of Education and Trade, then the Ministry of Trade and Agriculture in 1876, and the Ministry of Finance in 1878. The situation remained as such until the government issued Law No. 7 on June 2, 1919, by establishing a new ministry called the Ministry of Transportation ${ }^{40}$. After the state noticed that the work of transporting the messages was distributed among multiple departments, and each department belonged to a different ministry, the government made a decision to establish the Ministry of Transportation to include the Railways, Telephone and Telegraph, and Postal services. In addition, the regulation made the issuance of stamps a monopoly to the Egyptian government. It also determined the fees for transporting letters, which included regular, urgent, registered, and recommended letters. Now, the Post Authority currently affiliates with the Ministry of Communications and Information Technology.

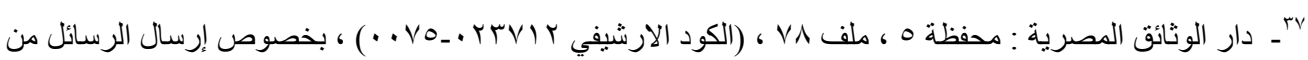

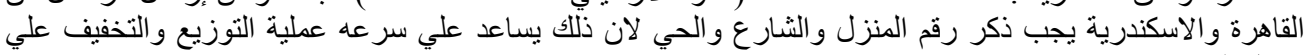

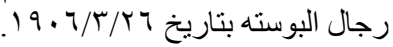

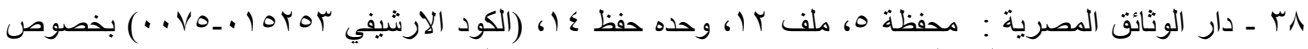

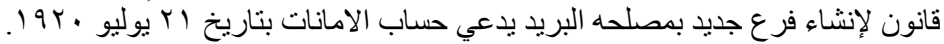

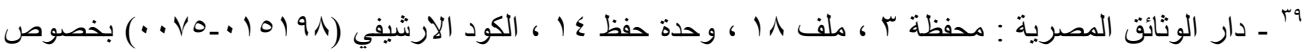

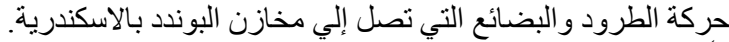

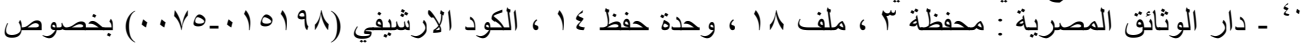

$$
\begin{aligned}
& \text { حركة الطرود و البضائع التي تصل إلي مخازن البوند الب بالاسكندرية. }
\end{aligned}
$$




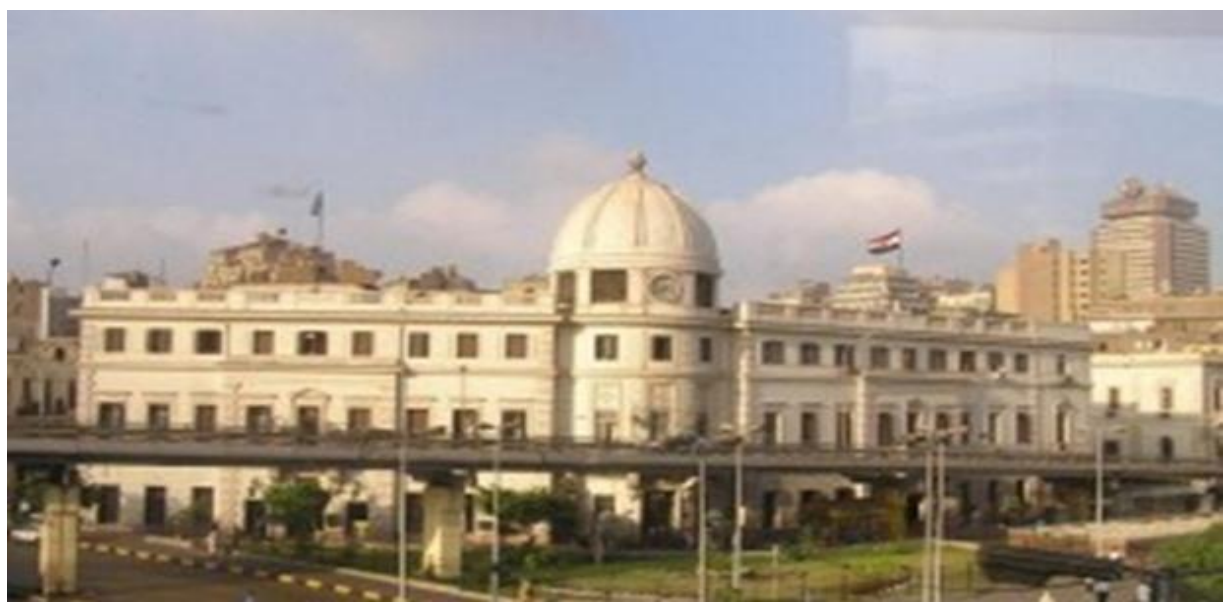

Fig. (5) of the General National Authority of Egyptian Post in which the museum was built at El Attaba. source: From the guide book of the post museum 1934

\section{The names of the Egyptian Post Authority have varied over 150 years:}

Initially, it was known as European Posta Company, which was established by "Carlo Mirati", but when Khedive Ismail purchased it in 1865 it became known as Egyptian Khedive Post.

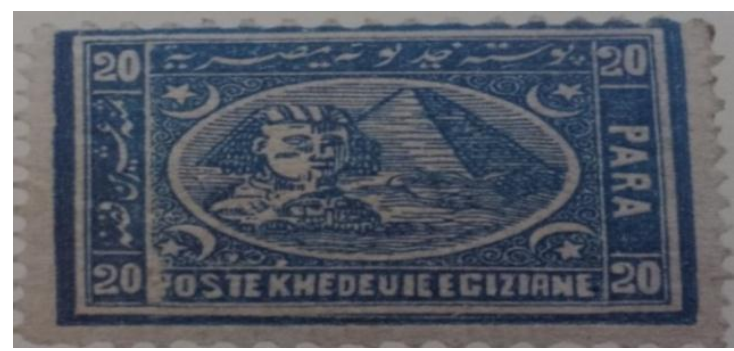

Fig. (6) of a postage stamp bearing the name of the Egyptian Khedive post. Source : Zeitouna,"150 years of Egyptian Postage 1866-2016"

The name continued until Khedive Tawfiq took over the country, and it became known as the Egyptian Posta, and the name remained unchanged until the end of Khedive Abbas Hilmi II's and Sultan Hussein Kamel's rule ${ }^{41}$.

41 - Zeitouna, "150 years of Egyptian Postage 1866-2016". 


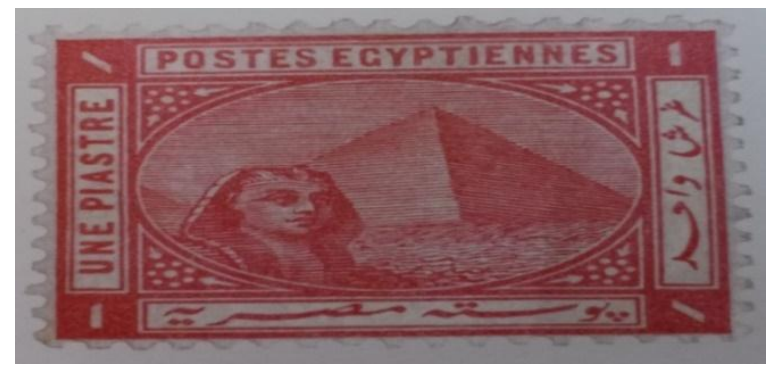

Fig. (7) of a postage stamp bearing the name of Egyptian Posta Source : Zeitouna ,"150 years of Egyptian Postage 1866-2016"

However, when King Fouad took over the reign of Egypt, the name was changed, and it became known as the Egyptian Post until the end of the reign of King Fouad and King Farouk.

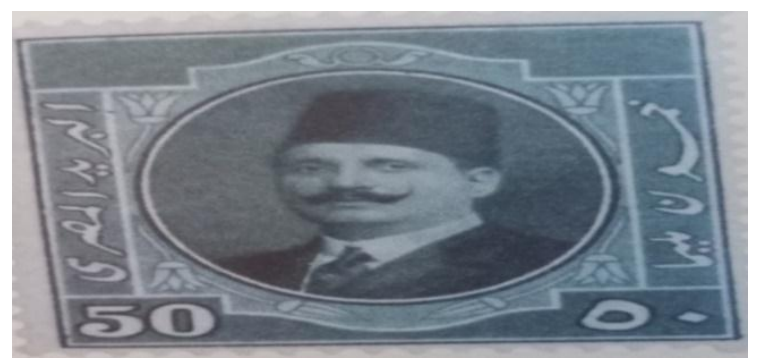

Fig. (8) of a postage stamp bearing the name of the Egyptian Post Source : Zeitouna ,"150 years of Egyptian Postage 1866-2016"

Then the name changed to become the General Authority of Egyptian Post after the revolution of July 23, 1952, When President Nasser issued a republican decree in 1957. Then the name changed from the General Authority of Egyptian Post to the Post Authority in 1966. The name continued until changed again during the reign of President Hosni Mubarak from the Post Authority to the National Authority of Egyptian Post in $1982^{42}$, and was affiliated with the Ministry of transportations. While in 1999 the Ministry of Communications and Information Technology was established to supervise the National Post Authority, the Egyptian Company and the National Institute of Communications. And this postal affiliation with the Ministry of Communications has contributed to modernizing its services and providing them in a more efficient and effective manner.

بـ ـ محمد فوزي عبدالقادر ، فيكتور انطون ابراهيم جرجس ، "رواد البريد المصري" ، (الهيئة القومية للبريد

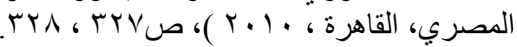




\section{Postman in Modern Egypt:}

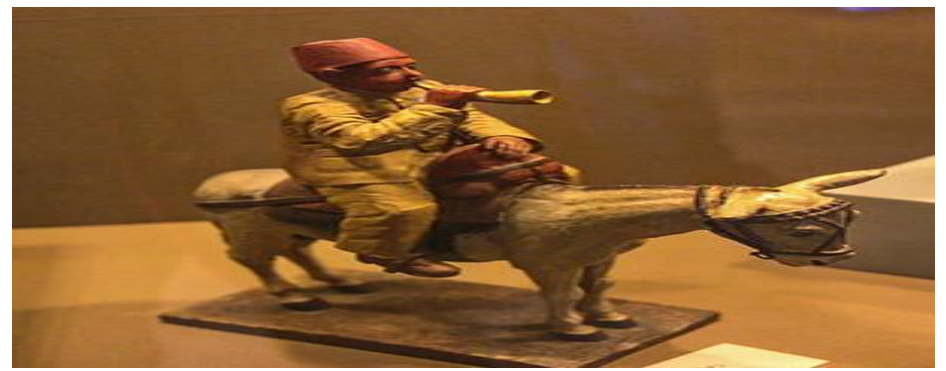

Fig. (9) Of a postman riding on a tail-cut mules

\section{Source: Post Museum at Al-Attaba "Photographed by the researcher"}

Since the dawn of history, humans have been writing their messages on wood planks, palm fronds, brick blocks or papyrus leaves. Then the letters became written on plain paper and put in an envelope sealed by the post offices. Then, it evolved with the appearance of post stamps ${ }^{43}$ which were put on letters $^{44}$. In addition, the development of means of transportation, after sending homing pigeons or messengers riding donkeys and horses to using bicycles and cars, then trains and planes.

With regard to the election of postmen, they were chosen from among the servants of the Sultan, who were known for their honesty, intelligence and competence. After being chosen for this task, they were distinguished by carrying a sign of their own, which was in the shape of a copper or silver plate where on one side of it is engraved "There is no god but God" and on the other side, "Mawlana Al Sultan, the Great King ...". This was the first attempt to distinguish postmen, as the Sultan used to give the faithful postmen many rewards in the country.

Not only were the post workers awarded bonuses in ancient times, but the Post Authority was concerned, from time to time, with encouraging post employees by giving them some badges, medals, and granting them promotions for the sake of their integrity and dedication to work. Below, we will present some historical documents from 1886 to 1920 that confirm the encouragement role that the Postal Authority offers towards its employees in order to ensure the continuity of providing a distinguished service to citizens.

43. The world's first postage stamp appeared in 1840 in England. With it's debut, the "hobby of collecting postage stamps" appeared, which many passionately sought out and had millions of amateurs all over the world.

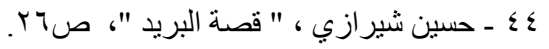


1- A memorandum submitted by the Ministry of Finance to the Khedive on March 31, 1886 at the request of the Director of the Khedive Post Department to grant the Monsieur "Lovic" a glorious nishan for his distinguished performance in the post office Movement ${ }^{45}$.

2- A memorandum submitted by the Ministry of Finance to the Khedive on December 18, 1887, regarding the request of the director of the Khedive Post Department to grant Monsieur "Chersik Bey", one of the authority's employees who was deposed to retirement due to the illness that he suffered from while in service, by granting him a third rank glorious Nishan as a reward for his service in the Authority. The matter was offered to the officials to be approved by the supreme Administration.

3- A memorandum submitted by the cabinet to the Khedive on July 3, 1888, based on the good testimony shown by the Ministry of Finance for Monsieur "Charters", the Public Prosecutor of the Post, by requesting granting him the second rank as a reward for him for his good services.

4- A memorandum submitted by the Ministry of Finance to the Khedive on September 24, 1891 for a certificate of entitlement to each of the following persons to obtain the glorious Nishan. They are as follows:

- Monsieur "William Sundus Charterus Bey", the agent of the Egyptian Post Department, a nishan of the third grade.

- Monsieur "Harbert Halton", a headmaster in the administration and inspection in the department, by granting him a fourth grade Nishan.

5- A letter from the Ministry of Finance to the Khedive on March 21, 1898, indicating that the general manager of the Egyptian Post Service made a good testimony for Monsieur "Luigi Purved", who was an employee in the authority with a salary 20 pounds per month. He retired on the first of March after serving for more than 30 years in the authority by granting him a glorious Nishan of the fourth degree, as a reward for his good service.

6- A letter from the Deputy Prime Minister dated 14 July 1900, based on the request of the minister of finance by granting the second rank to Monsieur "Albrno Campa Niano", who was the head of the Suez Post Administration and who retired after 31 years of service, with a 30 pounds salary after

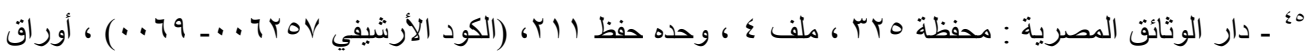

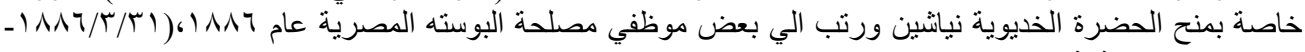
. $7:$ : 
winning the fifth Majestic Nishan in May 1885, and the third rank in April 1899.

7- A letter from the prime minister to the head of the Khedive Diwan on May 24, 1902, requesting granting the third rank to: "Muhammad Effendi," the head of the Emiri Correspondence Registry in the post of Egypt, and "Gerges Effendi", the head of the Liquidation Debt Registry and the Finance House of Egypt in the finance Ministery ${ }^{46}$.

8- A letter from the Prime Minister dated October 29, 1902, based on the request of the minister of finance, to grant the fourth rank Nishan to Monsieur "Moiseh Pazir", who was an employee in the General Department of Post as a chief of registry ${ }^{47}$.

9- A letter from the Prime Minister dated March 2, 1906, based on the request of the minister of finance, to grant a third rank Nishan along with the title of Bey to "Gerges Mark Effendi", who was a department chief in the General Post Department and he was the holder of the fourth rank in 1899.

10- A letter from the cabinet dated November 4, 1908 requesting granting the third rank to "Michael Effendi" who was the head of the General Department of Post.

11- A letter from the cabinet dated 4 July 1910, requesting granting the fourth grade glorious Nishan to "Paul Hanna Effendi," the head of the Post Department following his retirement.

12- A letter from the cabinet, dated 12 November 1911, requesting granting the third rank to "Salim Musa Effendi", who was an employee at the Post Department in Zagazig and the glorious Nishan from the fourth grade to Monsieur "Simon Idrissini", the agent of Ismailia post.

13- A memorandum from the Finance Committee of the Khedive Court on January 22, 1920 to approve the promotion of "Iskandar Ishaq Effendi", the

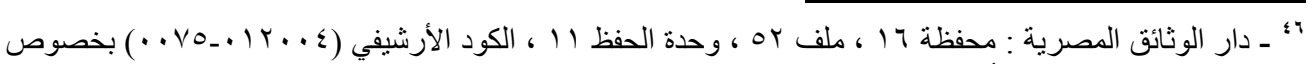

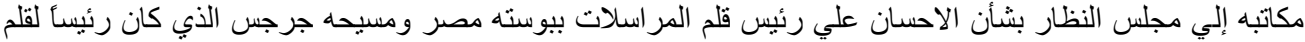

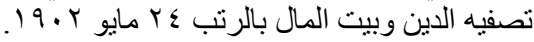

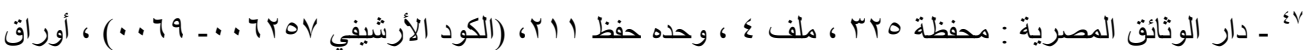

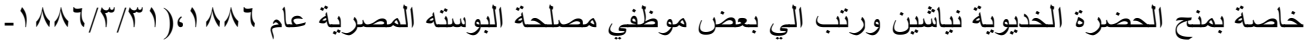
.11: V V
} 
agent of the administration at the Post Department, to the position of an account manager for that department ${ }^{48}$.

14- A memorandum from the Post Administration to the Finance Committee dated April 7, 1920 to approve granting "Mahmoud Hussein Al-Saidi", a writer in the Post Department, an allowance of 500 millimes per month. This is a reward for him for saving the post administration safe from theft, as it contained 400 messages insured by about 6 thousand pounds ${ }^{49}$.

The Post Authority was also concerned with its employees to provide all support for them starting from granting awards, promotions and Nishans in case of reward but in case any of its employees erred, then it directed the penalty and punishment to him to be an example to others. This is what happened with the postmen "Salah Ali Abdullah", "Abd al-Fattah Ahmed" and "Hamdi Ibrahim" when a deduction of 200 millimes was deducted from their salary on April 9, 1968 as there were letters with them that did not have clearance marks or post stamps. They should note this by reviewing their work before leaving the office ${ }^{50}$.

These historical documents are considered a small part of the vast documents belonging to the governor of the "Post Authority and the Ministry of transportations" that are kept in records in the National Archives House in Cairo that dealt with the efforts of post employees. We have presented this section to confirm the awareness of post officials in providing all "moral and material" support to its employees for the proper continuation of the service that was not limited to a specific person, category, nationality or a specific region, but also included all departments in all governorates. This is in appreciation of them for their continuous giving and sacrifices for the regularity of the post service in Egypt.

\section{Post Museum inside the Post Authority:}

King Fouad I ordered the transfer of the headquarters of the Post Administration from Alexandria to Cairo and remained in its current building in Attaba Square, due to the outbreak of the Second World War and in order

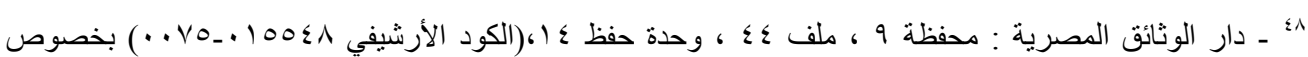

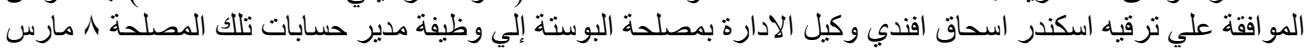

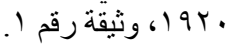

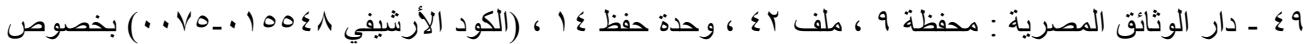

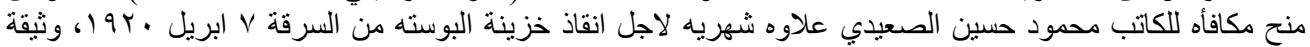

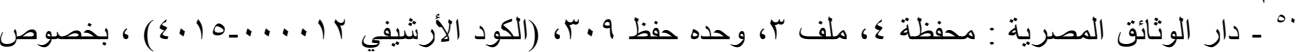

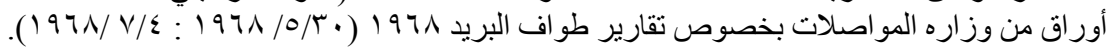


to ensure the continuity of the transportation of missions and not to delay them $^{51}$. In late 1930, he ordered the establishment of a post museum in the post Authority ${ }^{52}$. The museum was prepared to be on the second floor to preserve the history and objects of this ancient institution. The Authority had prepared the upper floor of its general administration, consisting of two halls containing ten sections. The museum had been coordinated in terms of historical arrangement to be a reference to the history of the Egyptian Post.

In a short period, King Fouad was able to present to Egypt many unprecedented achievements during his reign of Egypt. Despite the political turmoil during his reign, including internal revolutions, world wars, and international statements, such disturbances did not affect his love and appreciation for Egypt. Rather, he provided all support to his country educationally, culturally, economically and politically. King Fouad was also interested in holding many local and international conferences ${ }^{\mathbf{5 3}}$, besides establishing a lot of museums that contributed to a cultural and civilization renaissance in the history of the Egyptian people.

Due to King Fouad's appreciation of the importance of choosing Egypt as the seat of the Tenth World Postal Conference in $1934^{54}$, after the ninth International Post Conference in London in $1929^{55}$, he decided to move the headquarters of the main post office from Alexandria to Cairo in 1930. In the same year, he ordered the establishment of the "Fouad I Post Museum" in AlAttaba to be the first Museum in Africa and the Middle East. The Postal Authority started preparations for the establishment of the museum, by completing all the papers and searching for documents related to the history of the mail that is important to display in the historical section within the Post Museum to be created, in preparation for its opening in conjunction with the holding of the 10th Postal Conference in Cairo ${ }^{56}$.

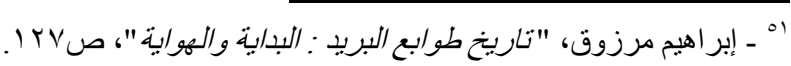

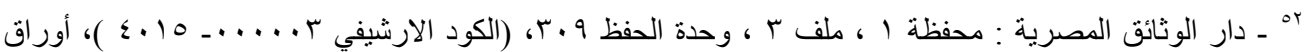

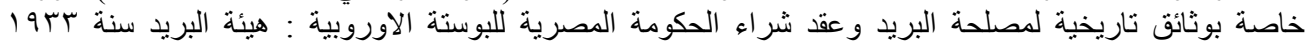

$$
\begin{aligned}
& \text {. (19Tr/V/10 - 19rr/ Tr/O }
\end{aligned}
$$

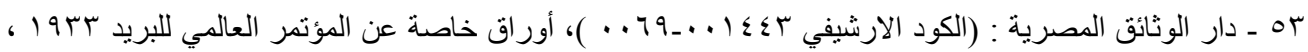

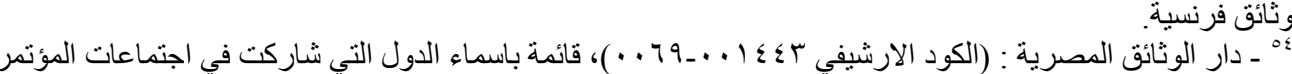

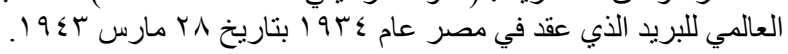

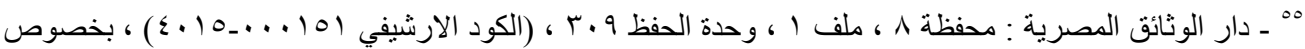

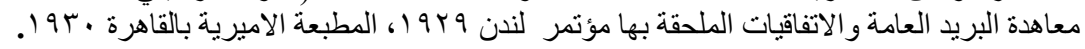

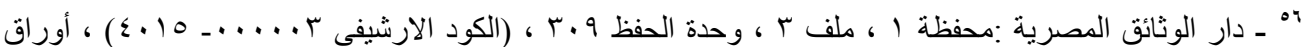

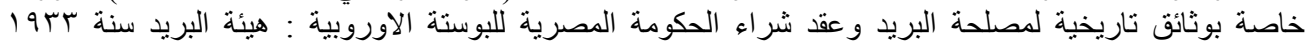

$$
\begin{aligned}
& \text {. (19Tr/ } / 10-19 T r / 1 Y / 0)
\end{aligned}
$$


When King Fouad I decided to establish a post museum inside the Post Authority, several ministries, managers, and employees offered to provide their assistance to the museum to be established, such as: the two Ministers of Egypt in London and Berlin, the directors of London, Brussels, Berlin, and Cairo museums, the staff of the School of Applied Arts, the Amiria Press, the Railway and Survey Authority, the directors of air and sea navigation companies, and the Federation Office in Switzerland who all wanted to provide all support to help the Egyptian Post Authority to establish its new museum $^{57}$.

Therefore, King Fouad ordered the establishment of a post museum in which he would include all the treasures of the past to show off and be proud of the history of Egyptian Post through the historical eras that had existed since the time of the Pharaohs. In addition, to emphasize that Egypt was a pioneer in the use of postal service transport systems before all peoples. He ordered a search of all historical documents to include everything related to the mail, especially documents related to the purchase of the European post company, which became an Egyptian company by Khedive Ismail in $1865^{58}$. So, he collected old letters and manuscripts to preserve them from loss ${ }^{59}$.

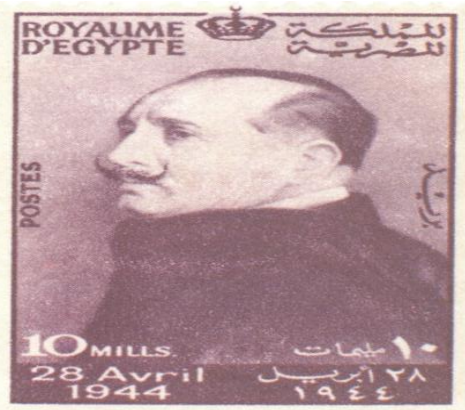

Fig. (10) of a stamp of King Fouad, the establisher of the Post Museum in Cairo. Source : Zeitouna ,"150 years of Egyptian Postage 1866-2016"

King Fouad was one of the most important stamp collectors ${ }^{\mathbf{6 0}}$ among a large group of kings, princes, presidents, and wealthy people from all over the world. This hobby becomes exciting when you start studying it, from which you discover new facts that make you feel amazing and extremely

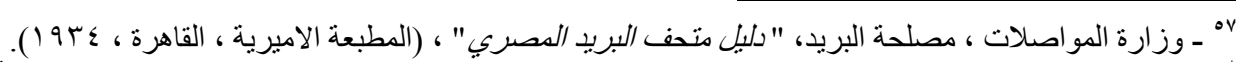

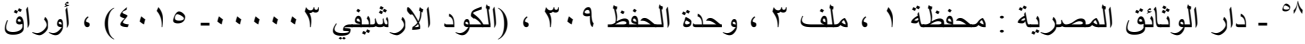

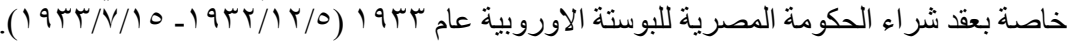

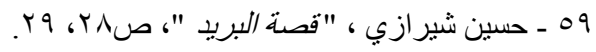

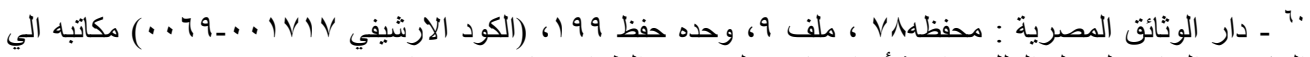

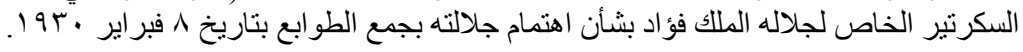


important $^{\mathbf{6}}$, so during his reign, many postage stamps were issued, including the first edition of King Fouad stamps in 1923. In 1925 the Postal Authority issued for the first time a set of commemorative stamps, including the International Geographical Conference in Cairo, and stamps to celebrate King Fouad's 58th birthday on April 2, 1926. In the same year, the Postal Service issued the first express postage stamps on November $28,1926^{62}$. In 1927, the postal authority issued the second edition of King Fouad's stamp versions ${ }^{63}$.

\section{Architectural description of the Post Authority:}

The building of the National General Authority for Egyptian Post, located at Al-Attaba Square, consists of three floors. The first floor or the ground floor is a large hall for postal services to the public, it is divided into many service outlets including receiving and delivery of mail and money, in addition to sending telegrams of congratulations, condolences, or wishes of recovery, an outlet for saving booklets, current accounts, an outlet for selling tickets of the Post Museum, newspapers, magazines, and another outlet for stamp collectors. There is also an office for receiving letters collected from mailboxes located in the streets.

The second floor or the first upper floor is the Post Museum ${ }^{64}$; this treasure is in two halls, one of which is the main hall, the grand hall, which includes nine sections next to the employees' offices. The other is the small hall that includes portraits of Egyptian rulers from the family of Muhammad Ali and stamps for all countries of the world, then the third floor for the administrative offices of the Posta Authority, it includes planning and inspection offices, an information center and offices of general managers for activities and service; also, offices for postal supervision, and financial and administrative affairs. On top of this floor is a large hall, topped by the dome and a clock similar to that of Cairo University.

There are post control offices in the building for public security, national defense, state security, and for the safety of those carrying parcels, prints and letters. So all departments and government authorities (customs department, ports, and in particular the Post and Telephone Departments) should provide all assistance and facilities needed for those responsible for post offices. This

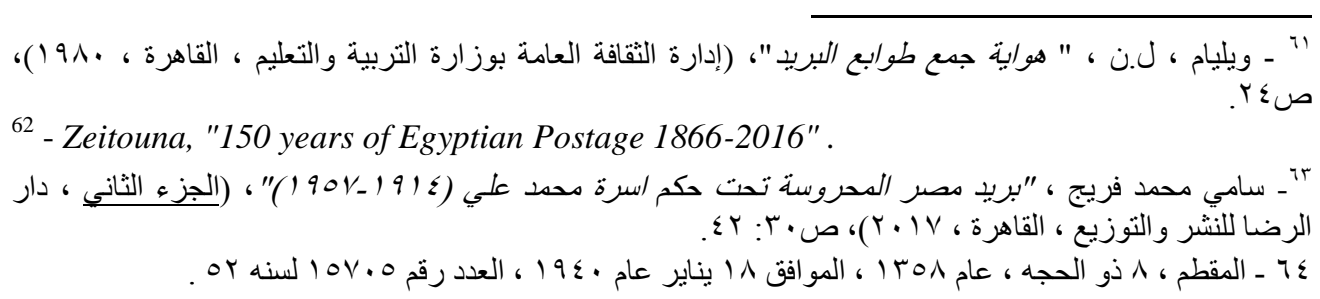


is mentioned clearly in the document issued in 1939 of the military order, which controls all correspondence through monitoring all articles of the mail to which the provisions of censorship apply, including newspapers, publications and telegrams.

In addition, the Post Authority was interested in completing the necessary preparations for the museum before the tenth world postal conference in Cairo in 1934, so that delegates of the countries could see the museum to be the best the evidence of the regularity of Egypt's postal system, with an emphasis on the cultural role the museum offers in supporting more cultural awareness. The establishment of the museum is also a clear evidence of adhering to heritage and national history to deepen the intellectual and sentimental spirit. In general, the museums are cultural and educational institutions, which is a clear standard for determining degree of progress and civilization.

In 1940, when the museum was officially opened to the public, the museum's instructions were different. The Post Authority decided to allow the public to enter the museum on Friday and Sunday of each week, with a fee of 20 to 10 milimes for students, in addition, an illustrated guide of the museum's contents was printed and sold for 50 millimes. This means that in the past the museum used to open only two days a week, but with the increasing number of stamp amateurs worldwide and the increase of cultural awareness, the museum became open throughout the week $^{65}$. At present, the museum belongs to the Ministry of Communications and Information Technology.

The museum is located on the second floor of the Post Authority, upon climbing the stairs and reaching this floor we find a large courtyard in the middle of which is a huge star on the floor. It is the center of Cairo from which the distance is measured between the Post Authority in Cairo and the post centers all over Egypt. In the middle of this star is a huge statue of Khedive Ismail who initiated the idea of purchasing the European Post and transferring it to the Egyptian Post Authority in 1865. 

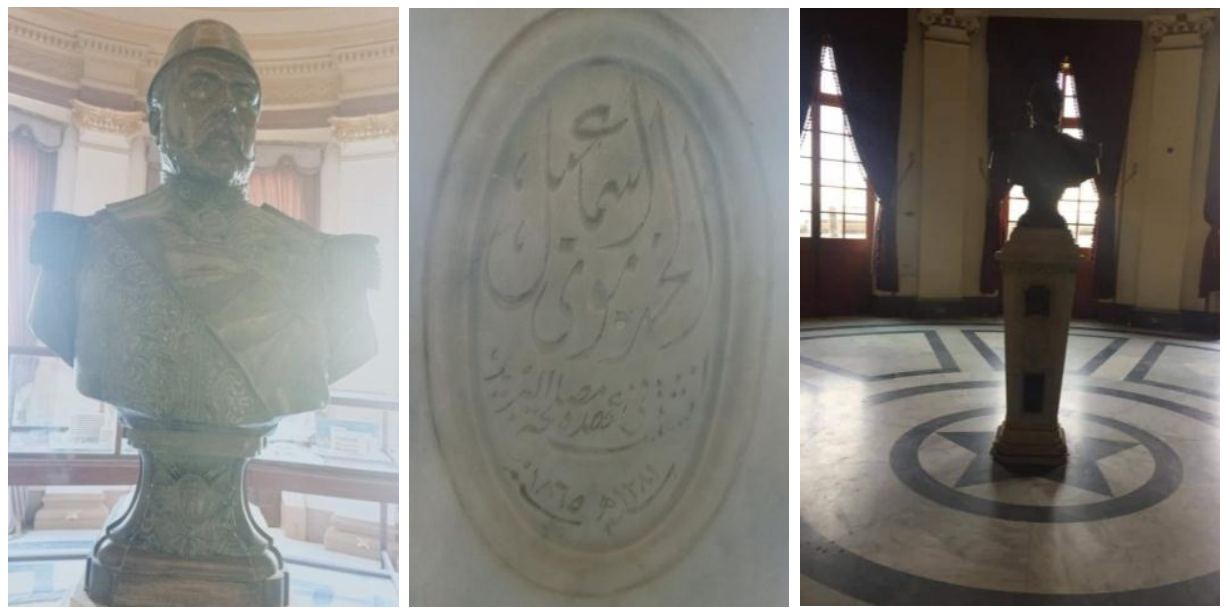

Fig. (11) of the statue of Khedive Ismail, founder of the Egyptian Post service.

Source : Post Museum at Al-Attaba "Photographed by the researcher"

Then there is a small corridor that leads to the museum's door, when reaching this door, we find some instructions from the Chairman of the Board of Directors of the National Post Authority to the staff and visitors. With regard to visitors, instructions include entrance fees of the museum, visiting times, and the outlet window in charge of selling the museum's tickets. As for the staff, they are instructed not to be present in the museum's administration, except for official work.

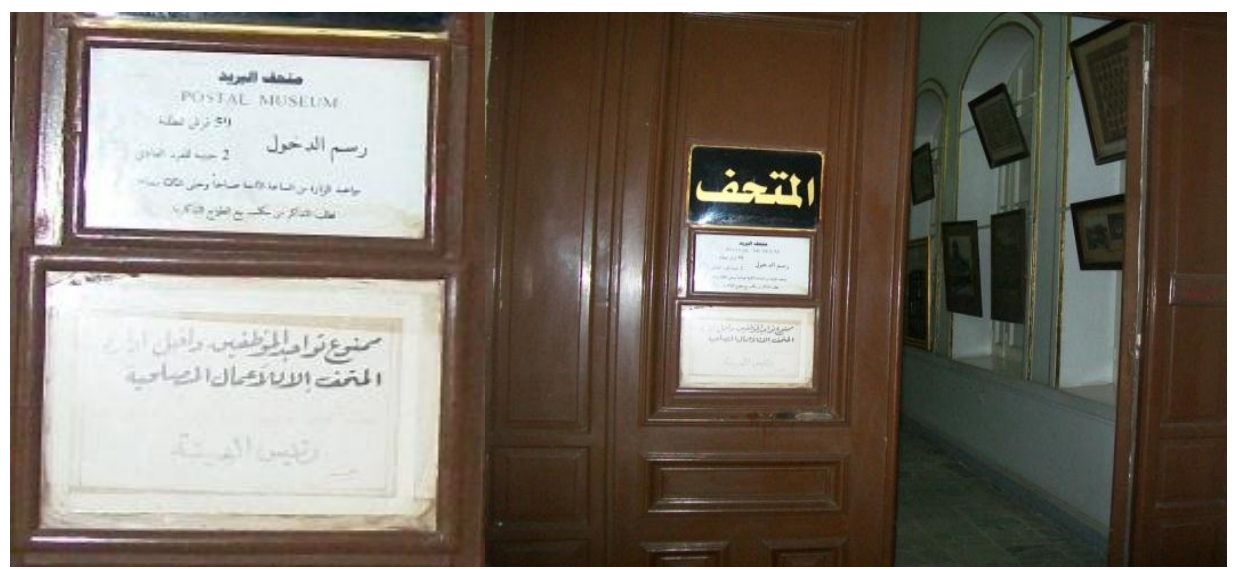

Fig. (12) of the museum door on the second floor, inside the Egyptian Post Authority.

Source : Post Museum at Al-Attaba "Photographed by the researcher" 
After entering through the wooden door leading to the Post Museum, we find a small corridor with a group of photographs, including a large honor board for members of the National Post Authority who took over management of the Authority since "Giaco Motsi", the first director in January 1865 until now. In addition to a group of pictures of members of some international conferences. Then we reach to the museum's two showrooms (halls). We find the small hall of the stamp section on the left, and the large hall of the other nine sections on the right.

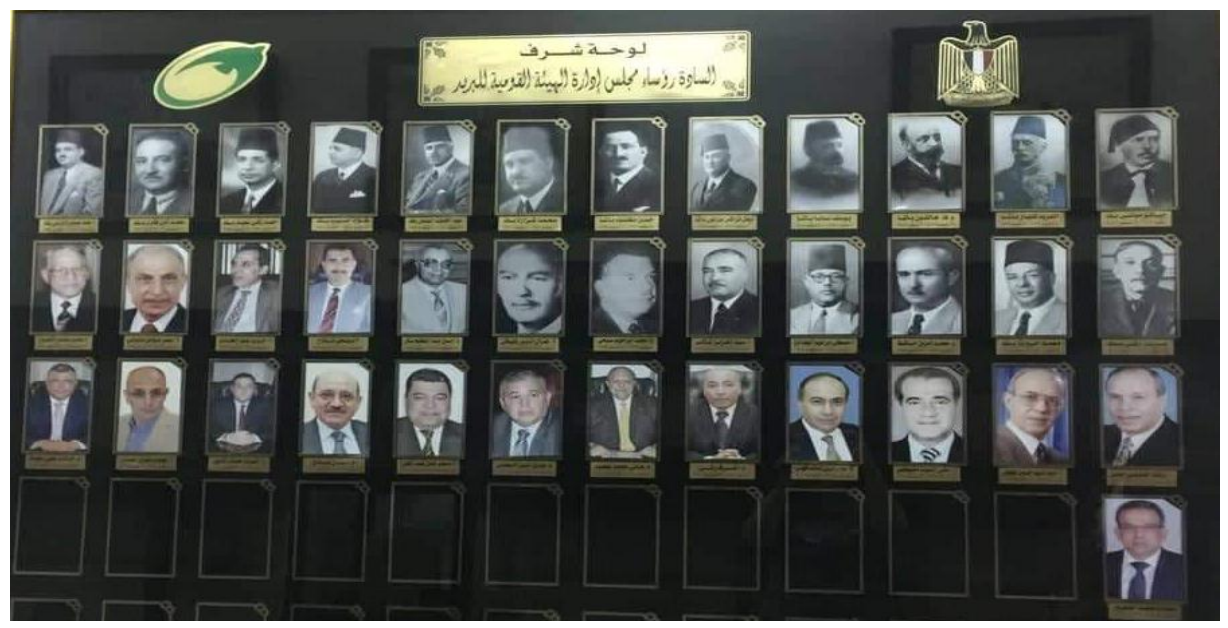

Fig. (13) of Directors of the National Postal Authority in Cairo

Source : Post Museum at Al-Attaba "Photographed by the researcher"

The large hall contains nine sections, in each section there is a large instructions board, inside each section there are information labels next to the artifacts in Arabic and French. The sections in the large hall include: the historical section which contains a collection of papyri, documents, old letters, contracts and mail regulations. The post tools section that contains bags, keys, letter boxes and scales. The clothing section that contains uniforms of the post personnel. The Statistics section and the transportation department, which contains all types of transportation used for mail, the old and modern. Seals section and the conference section, which contains memorial photos and gifts. The Air Mail section, which exhibit models of aircrafts, and finally the Foreign Mail section. ${ }^{66}$ 

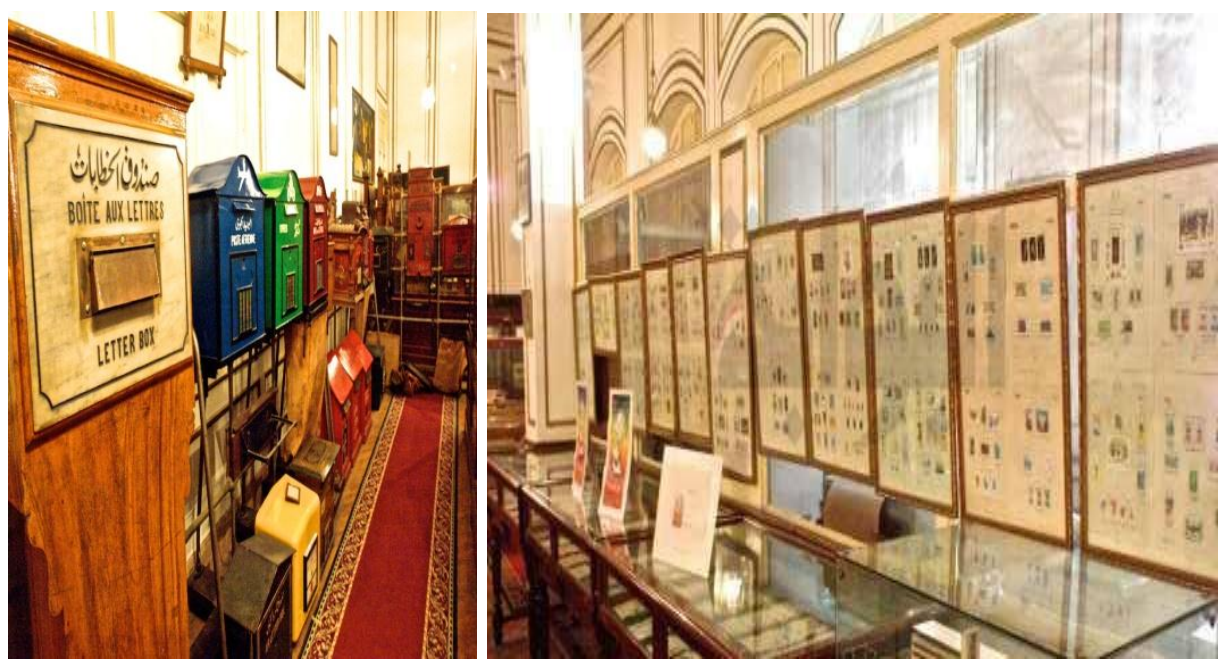

Fig. (14) of the Grand Hall of the Post Museum, before the renovation.

Source : Post Museum at Al-Attaba "Photographed by the researcher"

At the end of the large hall, we find a huge painting, it is a hand-drawn painting with Egyptian postal stamps, representing scene of the Great Pyramid and the Sphinx. It is a gift presented by an Italian artist to King Fouad I on the occasion of the establishment of the post museum in Cairo, in which is used 15,000 old stamps issued in 1912. ${ }^{67}$

On leaving the large hall, we find the small hall that contains everything related to the Egyptian stamps since they were issued in 1866 in all its categories, and stamps of many countries of the world, including European, Asian, African, American and others; a group of various papers and clichés ${ }^{68}$, in addition to a group of huge portraits of the Alawite family as Muhammad Ali Pasha, Khedive Ismail, King Fouad I and King Farouk, all of which are hung on the walls of the hall.

The Post Authority has organized the museum, increased its exhibits, and prepared a huge statue of King Fouad I. As soon as the statue was completed, King Farouk officially opened the museum to the public. The Post Authority also exchanged information on the history and stamps of the Egyptian Post with a group of international newspapers that reached 395 types of daily, weekly and monthly newspapers and magazines in 1938, including 258 Arab

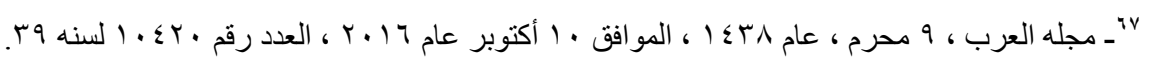

68- Ministère des communications : Administration des postes ‘"Guide du Musée postal égyptien،(Imprimerie National Le caire، 1934) P 7: 10. 
magazines, 12 eastern and western magazines, 119 European magazines, 19 Eastern European magazines ${ }^{69}$.

When the Post Authority took the measures for the opening ceremony, it was officially opened to the public on January 18, 1940 after completing its tools and exhibits and preparing it for public visit. The museum contains many objects related with the history of the Egyptian Post. The most important of them is the historical section that contains samples of the development of writing and the transmission of the letter cross the different eras. It also includes a section for conferences that contains pictures of members of the international postal conferences from 1874 to $1939^{70}$ in addition to postal treaties and agreements of each conference ${ }^{71}$. In addition, other sections on postal tools, maps, statistics, mail boxes, transportation, and Egyptian and foreign stamps ${ }^{72}$.

After the 23 July 1952 Revolution, a separate budget was allocated to the Post Authority. It had the right to direct its surplus revenues to the work of improving and promoting postal service. After the declaration of the Republic and the abolition of ownership, the Egyptian Post Authority turned to the General Post Authority by a decree from the President of the Republic in 1957. In the same year, the Authority established an office for collecting post stamps in Egypt and abroad, where the office participates in exhibitions that display post stamps from all over the world. In 1959, a post magazine was established and edited by the authority's employees, as a beacon to spread cultural awareness among the public. In the same year, a system of civil services was introduced such as post offices and post agencies.

Also, the Post Authority had set up its own printing press to print the ordinary and commemorative stamps. It was opened on July 23, 1961 in Nasr City, Abbasiya ${ }^{73}$, and this press was one of the largest press houses in the

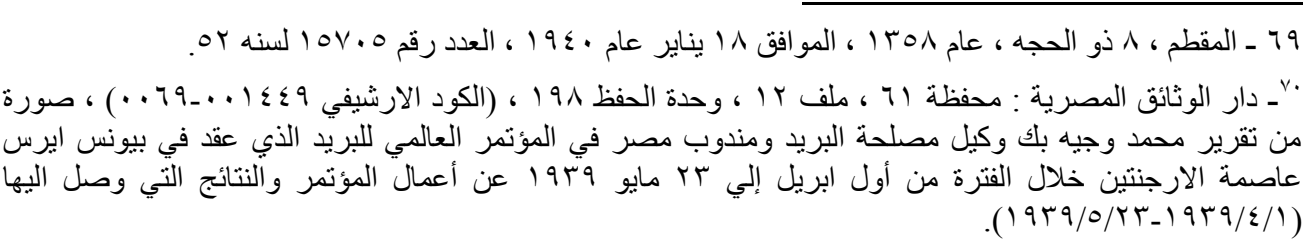

71- Ahmed Yasser، "postal Museum : Reference for stamp Collectors in Egypt"، in Sada Elbalad journal، Wed. 19/12/2018 -24/1/2019، 12: 26 pm، (Thur).

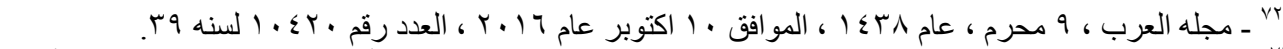

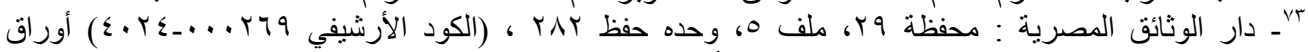

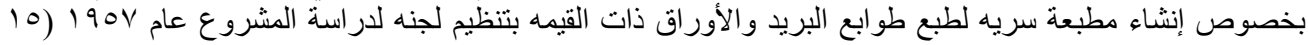

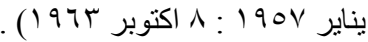


Middle East ${ }^{74}$. In 1966, the authority opened 54 government post offices and 25 postal agencies ${ }^{75}$. In 1970, a law was issued regarding the post system, and the authority committed the landlord who owned a building consisting of two floors or more, to put a mailbox for each flat. The law also stipulated that it is not permissible for one person to have more than one savings book ${ }^{76}$. It is also forbidden for the post employees to give any data to others regarding the amounts deposited in the savings fund except upon the permission of the court in April 8, $1970^{77}$.

\section{Conclusion}

There is no doubt that the Egyptian Post Authority is one of the most ancient institutions with a long history that always strives towards developing its services to serve the community. That can be achieved by working within the framework of a comprehensive plan that aim at improving the level of services provided to citizens in accordance with the international standards. It can also be achieved by providing all the different postal services at all levels. That reflects the boom that the Egyptian Post is currently witnessing in terms of improving and developing the level of performance. This confirms the importance of the postal role as the backbone of peoples' daily life and its important impact on the economic, cultural, political, social and administrative fields.

Egypt is one of the oldest countries in the world that witnessed the emergence of postal services. This is evidenced by the objects preserved inside the museum, which contain pictures, maps, a group of graphs, and models of the development of the Egyptian postal service throughout ages. In addition, the Egyptian Post Authority also confirms that the date of the first document in which the term "post" was mentioned dates back to 2000 years $\mathrm{BC}$.

Credit of founding the Egyptian Post goes to Khedive Ismail, who purchased the European Posta Company in 1865. Its main headquarters was in Alexandria as it was close to the Khedival Post Company. Until King Fouad

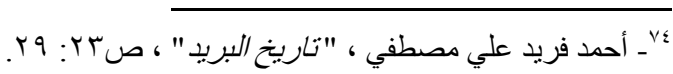

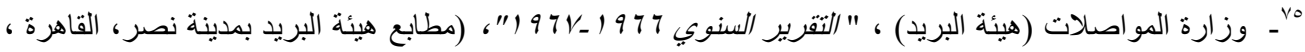

$$
\begin{aligned}
& \text { r }
\end{aligned}
$$

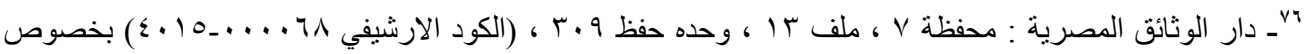

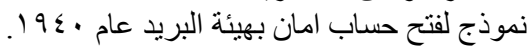

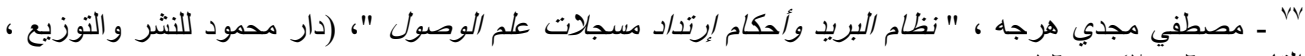

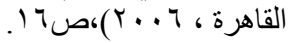


ordered to move the main headquarters of the post services from Alexandria to Cairo in 1930.

There is no doubt that the Post Museum is a national historic landmark that cannot be removed from the glorious history of Egypt. It is one of the great historical museums that narrate the history of the Egyptian Post in a new way that displays a collection of models (dioramas) of the means of transporting mail in the past and present, and samples of Egyptian and foreign stamps. In addition to a collection of important documents dating back to the establishment of the Egyptian Post, as well as models of post offices in various eras. This museum is located inside the building of the Egyptian Post Authority at Al-Attaba.

According to the photographs found inside the Post Museum, they show the difficulties that the postman encountered in transporting the letters. He used to write his will before leaving due to the monsters, attacks and bandits. We have previously mentioned that the post authority grants medals and promotions to its employees in case of commendation, but in case one of makes a mistake, it applies a punishment to be an example to others. 